\title{
Chapter 3 \\ Blurring of the Transition Point: \\ Combining Work and Study
}

\subsection{Introduction}

Over the past few decades, youth researchers have argued that school-to-work transitions have become more complex and prolonged due to new conditions in European labour markets and education systems (Wyn and Dwyer 1999). One widely acknowledged reason for this prolongation is the expansion of higher education, which is increasingly accompanied by growing participation in part-time student employment. The fact that more young people are combining work with studying means that their education is overlapping their occupational career. This poses the question of when exactly the transition to the labour market begins and ends for young people (du Bois-Reymond 2009a). To gain a better understanding of transition experiences today, it is necessary to analyze the dynamic interplay of the multiple transitions that are taking place simultaneously (Schoon and Silbereisen 2009).

In order to scrutinize the complexity of transitions, I will study whether, and if so how, my respondents combine their studies with work throughout their trajectories in order to understand the influence of work-school combinations on the transition process. Previous studies have suggested that student employment is mostly undertaken for financial reasons, such as paying for tuition costs or sustaining a consumer lifestyle, and in order to gain the credentials needed to secure a full-time position in the labour market (Brooks 2006). Student employment practices familiarize young people with the world of work, where they can accrue occupational skills, orient themselves towards the labour market and discover more about what actually motivates them. However, working can also have negative implications for students' educational careers in the form of falling grades or even dropping out of education entirely, depending on the type of job, working conditions and hours of employment (McNeal 1997; Ruhm 1997). Consequently, student employment is in many ways a critical activity during the transition process. 
Research in the Netherlands and France has documented a significant increase in student employment since the 1990s. In the Netherlands, student employment (called a bijbaan in Dutch) refers to a student job for around $12 \mathrm{~h}$ per week during one's study programme. According to CBS statistics, in 1992 one third of students between the ages of 15 and 24 worked at least $12 \mathrm{~h}$ per week during the course of their studies. By 2001, this percentage had increased to more than 50\% (Lucassen 2003). Between 2001 and 2014, when the respondents of this study were still at school, the rate of working among all active students fluctuated between $50 \%$ and $60 \%$ (CBS 2012). Looking at older age groups, Riele and Siermann (2007) showed that $80 \%$ of Dutch students between the ages of 20 and 24 reported having a regular job for at least $12 \mathrm{~h}$ per week, with $60 \%$ of them working more than $12 \mathrm{~h}$. Similarly, in France, student jobs refer to both regular jobs for $12 \mathrm{~h}$ per week and small, irregular jobs (petit-boulots). According to the 1998 Generation Survey, $70 \%$ of students reported having had some sort of a job during their studies, although only $11 \%$ of these jobs were on a regular basis (Cereq 2001). In the 2004 Generation Survey, participation in student jobs had increased to $75 \%$ while regular employment had reached 17\% (Cereq 2007). Although these figures apply to the period when the respondents of the study were still at school, student employment continues to be a significant phenomenon in France. According to the most recent 2010 Generation Survey, $68 \%$ of students reported having a side job while $16 \%$ had a regular job and the remaining 52\% had a summer job (Cereq 2014).

As previous studies have shown that there is a lack of focus on student employment with regards to its impact on the occupational careers of 'second generation' groups (Kasinitz et al. 2008). There is very little research on the student employment patterns of the descendants of immigrants in the Netherlands and France. Nevertheless, certain trends are discernible in the existing statistics. First, the participation of descendants of immigrants in student employment has increased in the last few decades in the Netherlands, though these students are less likely to combine work and study compared to their peers with native-born parents (Lucassen 2003; Wolbers 2008). However, neither Lucassen (2003) nor Wolbers (2008) distinguish between immigrants and their descendants. As a result, it is not clear whether the descendants of Turkish immigrants combine work and study less often than the children of natives. In France, previous research has shown divergent patterns of student employment based on family socioeconomic standing. For example, the children of managers and executives are more likely to work in jobs related to their studies, and thus have better chances of transitioning to the labour market through these jobs, compared to children from low and middle-income families (Béduwé and Giret 2004). Lower status jobs also mean precarious working arrangements and more strenuous work conditions that are more likely to lead to drop out or failure at school in France (Pinto 2010).

First, I will delineate the structural contexts of student employment in Amsterdam and Strasbourg with a particular emphasis on the labour market context and student financing mechanisms in the years 2005-2009 when the respondents were interviewed. Second, I use TIES data to describe student employment practices among children of Turkish immigrants in Amsterdam and Strasbourg. Since financial 
reasons form the major motive for student employment, a detailed overview of the financial position of the students in both settings is provided. The descriptive analysis from the TIES survey is amplified with qualitative interviews to understand the motivations behind student employment practices and the implications of working while studying for the transition process. Accordingly, the chapter examines whether the work activity has different consequences in terms of the development of forms of capital, especially work-related social capital and information capital, and whether the experiences of young people vary across the two cities.

\subsection{Structural Contexts for Student Employment in the Netherlands and France from 2005 to 2009}

\subsubsection{Labour Market Contexts}

The growth of student employment in the Netherlands has primarily been interpreted as a sign of increased labour market flexibility (Van der Meer and Wielers 2001). Delsen and Poutsma (2005) have argued that increased flexibility in the working practices of the Dutch labour market has led to a rise in the number of temporary contracts and part-time employees. Accordingly, students are seen as one of the most eligible groups for jobs with flexible hours, temporary contracts and low wages - to the extent that in some cases they have even replaced senior workers with low education levels who require greater employment security and stability (Van der Meer and Wielers 2001). In the case of France, recent reforms to promote flexibility in the labour market have resulted in an increase in temporary contracts. However, the effect of this reform was to preserve reasonably high levels of job security among senior workers ("insiders"), but to lower them among new entrants, especially young workers ("outsiders") (Jamet 2006). Consequently, young people are more vulnerable to precarious working arrangements, such as short-term contracts and repeated periods of unemployment (Zdrojewski et al. 2008). Under such circumstances, student employment opportunities are limited and characterized by temporary contracts, flexible working hours and low job security. The French government has recently begun to use new legislation ${ }^{1}$ and official reports to promote student employment, identifying it as a means of gaining autonomy and professional experience while improving integration into the labour market (Bérail 2007). However, left-wing parties and student unions in France consider work-study situations as an indication of financial need due to a lack of sufficient government funding.

\footnotetext{
${ }^{1}$ For example, a law has been passed that allows universities to employ their own students in administrative positions at school (Bérail 2007).
} 


\subsubsection{Student Finance Systems}

Another factor in the proliferation of student employment in both countries are the reforms to their financial aid systems. In the Netherlands there has been a gradual transfer of financial responsibility from the government to higher education students through reforms in the financial system (Vossensteyn 1999) since 1986. Prior to 1993, the state provided a basic grant (basisbeurs) to all students older than 18 attending post-secondary vocational education (MBO) or tertiary education (HBO, WO), which was higher for students living away from home. The children of lowincome families received a supplementary grant based on a means test, ${ }^{2}$ and all students were allowed to take out extra loans. Furthermore, all students received a travel pass to use either during the week or on weekends. However, after 1993 this system changed with the introduction of performance-based grants (prestatiebeurs), which transformed both basic and supplementary grants into conditional grants. Students did not have to repay their grant if they graduated successfully, but should they fail to graduate, the grant would be converted into an interest-bearing loan (Eurydice 2007). Even before the reform, student organizations were claiming that educational grants were substantially below student expenditure (Vossensteyn 2002). Under the new measures, students had to take out loans with interest, depend on a parental contribution or take a student job. Most students preferred a part-time job to extra loans as they already faced the risk of having to repay their grant should they fail to graduate (ibid). The new legislation not only increased student employment, but also rendered students' socioeconomic background more significant. Students from privileged backgrounds could rely on parental support, while those from lower income families became obliged to depend on student employment or loans.

The French student assistance system has also been criticized for its inadequacy with regard to both the amount disbursed and the number of students benefitting from it. In France, unlike in the Netherlands, only students in tertiary education programmes (BTS or university) can benefit from scholarships, and only the children of low-income families can benefit from government assistance programmes. ${ }^{3}$ According to a survey by OVE, only $30 \%$ of French students reported having received some sort of student financing, most of whom came from low-income families (OVE 2006). According to the official report by Wauquiez (2006), most middle-class students are excluded from the collective aid system because they are not considered "poor" enough, and most of them resort to parttime employment to finance their expenses. However, state assistance constitutes the smallest proportion of income for all students-the highest contributor is the income gained from student employment (OVE 2006). In 2008 the student financial aid system was overhauled to make it more accessible. Under the new reforms,

\footnotetext{
${ }^{2}$ While the basisbeurs is the same amount for all students (around $€ 100$ ), the supplementary grant can bring scholarships up to approximately $€ 400$.

${ }^{3}$ There is a six-level system, in which a student's rank is determined by parental income, whether they live with their parents and the number of siblings studying. Those in Level 0 receive no aid and those in Level 6 can receive up to $€ 450$ per month.
} 
social criteria scholarships are dependent on the income of the parental household, the number of dependent children, and the distance from the household to the student's place of study (Eurydice 2008). Social criteria grants can be supplemented by merit aids based on students' grades or educational success and there is also a new national emergency fund for cases where existing funds are insufficient to cover financial needs. Additionally, a new student loan system was implemented in the academic year 2008-2009 with the aim of increasing access to such funding while also bringing diversity to the ways in which students finance their studies. The state now also provides funds for accommodation and food. Unlike in the Netherlands, where students must complete a certain number of academic credits per semester depending on their course of study to sustain their grants, French grants are not automatically converted into loans if a student fails to complete his or her academic programme.

\subsubsection{Education System and Labour Market}

As discussed in Chap. 1, the Netherlands and France differ from each other in terms of the ways in which individuals acquire occupational skills in the education system, and how these skills are recognized in the labour market. The Dutch education system has a strong vocational orientation, through which professional skills are acquired at higher secondary and tertiary vocational schools, and students are often expected to conduct rather long internships or traineeships (Mueller and Gangl 2003). Conversely, France has a less vocationally-oriented education system in which professional skills are gained mainly through on-the-job training (ibid). Despite new developments in vocational tertiary education in France, where the role of employers and internships are encouraged, (Powell et al. 2009), professional tertiary education and vocational tracks still typically require much shorter internship periods compared to the Netherlands (Pigeaud et al. 2009; Visser 2010). ${ }^{4}$ These differences may have an effect on student employment practices, as gaining work experience is more valued and even promoted by the education system in the Netherlands than in France. A study by Wolbers (2003) using EULFS, showed that, in addition to the higher levels of participation in apprenticeships or internships, student employment is also more common in the Netherlands than in France. High participation in internships, which are institutional forms of work-study combinations fostered by educational institutions and the labour market, creates and promotes student employment in the Netherlands.

\footnotetext{
${ }^{4}$ According to CEDEFOB's Vocational Education and Training (VET) reports, most vocational programmes in the Netherlands require at least $20 \%$ of study time to be spent working for a minimum of 6 months, while the internship requirement in France is only 4-6 weeks.
} 


\subsection{Work-Study Combination in Amsterdam and Strasbourg}

\subsubsection{Nature of Student Employment}

The TIES Survey is cross-sectional and only provides a snapshot of respondents' activities. Table 3.1 shows the distribution of activities reported by the descendants of immigrants from Turkey at the time of the survey. Since the current chapter is about student employment practices, the data analysis will only focus on students, who form $37.2 \%$ of the sample in Amsterdam and 30.1\% in Strasbourg. This group includes those who are combining work and study, doing an apprenticeship or only studying (marked in bold in Table 3.1). Those who are not studying will be excluded from the analysis.

Table 3.1 already demonstrates that more students in Strasbourg reported "only studying" in comparison to those in Amsterdam. Table 3.2 makes it even clearer: among those who were still in school $51.1 \%$ of descendants of Turkish migrants in Amsterdam reported working and studying in comparison to $21.1 \%$ of the students with a Turkish background in Strasbourg. This points to a stark contrast between the two settings.

Table 3.1 Respondents' current activity

\begin{tabular}{l|l|l|l|l|l|l}
\hline & \multicolumn{3}{|c|}{$\begin{array}{l}\text { Descendants of immigrants from } \\
\text { Turkey in Amsterdam }\end{array}$} & \multicolumn{3}{l}{$\begin{array}{l}\text { Descendants of immigrants from } \\
\text { Turkey in }\end{array}$} \\
\cline { 2 - 7 } & Male & Female & Total & Male & Female & Total \\
\hline Working & $44 \%$ & $32.8 \%$ & $38 \%$ & $59.8 \%$ & $39.4 \%$ & $47.2 \%$ \\
\hline Work and study & $\mathbf{2 2 \%}$ & $\mathbf{1 6 . 4 \%}$ & $\mathbf{1 9 \%}$ & $\mathbf{6 . 2 \%}$ & $\mathbf{6 . 5 \%}$ & $\mathbf{6 . 3 \%}$ \\
\hline $\begin{array}{l}\text { Apprenticeship/ } \\
\text { internship }\end{array}$ & $\mathbf{4 . 6 \%}$ & $\mathbf{8 . 6 \%}$ & $\mathbf{6 . 8 \%}$ & $\mathbf{1 \%}$ & $\mathbf{0 . 6 \%}$ & $\mathbf{0 . 8 \%}$ \\
\hline $\begin{array}{l}\text { Inactive (sick or not } \\
\text { seeking work) }\end{array}$ & $4.6 \%$ & $4.7 \%$ & $4.6 \%$ & $4.1 \%$ & $2.6 \%$ & $3.2 \%$ \\
\hline Caring for children & 0 & $18 \%$ & $9.7 \%$ & $1 \%$ & $11 \%$ & $7.1 \%$ \\
\hline Unemployed & $9.2 \%$ & $11.7 \%$ & $10.5 \%$ & $9.3 \%$ & $14.2 \%$ & $12.3 \%$ \\
\hline Only studying & $\mathbf{1 5 . 6 \%}$ & $\mathbf{7 . 8 \%}$ & $\mathbf{1 1 . 4 \%}$ & $\mathbf{1 8 . 6 \%}$ & $\mathbf{2 5 . 8 \%}$ & $\mathbf{2 3 \%}$ \\
\hline Total (N) & 109 & 128 & 237 & 97 & 155 & 252 \\
\hline Sounc: & & & & & & \\
\hline
\end{tabular}

Source: TIES Survey 2008

Table 3.2 Participation in student employment at the time of the survey

\begin{tabular}{l|l|l|l|l|l|l}
\hline & \multicolumn{3}{|l|}{$\begin{array}{l}\text { Descendants of immigrants from } \\
\text { Turkey in Amsterdam }\end{array}$} & \multicolumn{3}{l}{$\begin{array}{l}\text { Descendants of immigrants from } \\
\text { Turkey in Strasbourg }\end{array}$} \\
\cline { 2 - 7 } & Male & Female & Total & Male & Female & Total \\
\hline Work and study & $52.2 \%$ & $50 \%$ & $51.1 \%$ & $24 \%$ & $19.6 \%$ & $21.1 \%$ \\
\hline $\begin{array}{l}\text { Apprentice/ } \\
\text { internship }\end{array}$ & $10.9 \%$ & $26.2 \%$ & $18.2 \%$ & $4 \%$ & $2 \%$ & $2.6 \%$ \\
\hline Only study & $37 \%$ & $23.8 \%$ & $30.7 \%$ & $72 \%$ & $78.4 \%$ & $76.3 \%$ \\
\hline Total (N) & 46 & 42 & 88 & 25 & 51 & 76 \\
\hline
\end{tabular}

Source: TIES Survey 2008 
Table 3.3 Qualitative profiles for work and study

\begin{tabular}{l|l|l|l|l|l|l|l}
\hline & \multicolumn{5}{l}{$\begin{array}{l}\text { Descendants of immigrants from } \\
\text { Turkey in Amsterdam }\end{array}$} & \multicolumn{4}{l}{$\begin{array}{l}\text { Descendants of immigrants from } \\
\text { Turkey in Strasbourg }\end{array}$} \\
\cline { 2 - 8 } & Male & Female & Total & Male & Female & Total \\
\hline $\begin{array}{l}\text { Regular (and irregular) } \\
\text { employment }\end{array}$ & 13 & 11 & 25 & 5 & 4 & 9 \\
\hline $\begin{array}{l}\text { Irregular employment } \\
\text { only }\end{array}$ & 0 & 0 & 0 & 6 & 3 & 10 \\
\hline $\begin{array}{l}\text { Didn't combine work } \\
\text { and study }\end{array}$ & 0 & 1 & 1 & 1 & 5 & 6 \\
\hline Total & 13 & 12 & 25 & 12 & 12 & 25 \\
\hline
\end{tabular}

Source: Qualitative interviews

Even though it has no statistical representation, the study's qualitative data showed a similar trend. The qualitative fieldwork included 25 interviews with students in Amsterdam and 25 in Strasbourg, discussing their education-to-work transition processes. The interviews revealed that student employment is a significant experience for young people and information was gathered on the students' employment histories, circumstances under which they sought work, and their reflections on their employment experiences. In Table 3.3, student employment activities are summarized with regard to my respondents' past and current experiences. "Regular and irregular employment" refers to situations in which students worked on a regular basis during the course of their schooling for at least a period. The same respondents might also have worked irregularly at some point, but they remain in this category. "Irregular Employment only" refers to cases in which students worked only in irregular jobs during summer breaks or holidays or at short intervals during vacations, but never regularly during their course of studies. This distinction is intended to highlight the regular nature of student employment, especially in Amsterdam.

As in the findings from the TIES survey samples, work-study practices were found to be more common in Amsterdam. Since the qualitative interviews were able to account for occupational histories, we obtained more detailed information on student employment in Strasbourg. In Amsterdam, almost all the respondents had a job throughout their studies, except for one person who dropped out of school after lower secondary education (VMBO) hence could not combine work with study and started working immediately. In Strasbourg, more than half of the surveyed youths combined work and study, though female respondents held part-time jobs less frequently. In contrast to Amsterdam, there was also more variation in work-study combinations in Strasbourg, with a mix of regular and irregular employment, or no employment at all.

Table 3.4 presents characteristics and regularity of the student jobs in the TIES data. Full-time jobs are defined as being 32 or more hours per week, versus parttime jobs, which are 31 or fewer hours per week.

In Amsterdam, most of the TIES survey respondents worked in part-time jobs with temporary contracts. However, their jobs appear quite stable as most reported 
Table 3.4 Nature of student employment

\begin{tabular}{|c|c|c|c|c|c|c|}
\hline & \multicolumn{3}{|c|}{$\begin{array}{l}\text { Descendants of immigrants from } \\
\text { Turkey in Amsterdam }\end{array}$} & \multicolumn{3}{|c|}{$\begin{array}{l}\text { Descendants of immigrants from } \\
\text { Turkey in Strasbourg }\end{array}$} \\
\hline & Male & Female & Total & Male & Female & Total \\
\hline $\begin{array}{l}\text { Full time work } \\
\text { (vs. part time work) }\end{array}$ & $\begin{array}{l}12 \% \\
(88 \%)\end{array}$ & $\begin{array}{l}19 \% \\
(81 \%)\end{array}$ & $\begin{array}{l}15 \% \\
(85 \%)\end{array}$ & $\begin{array}{l}67 \% \\
(33 \%)\end{array}$ & $\begin{array}{l}40 \% \\
(60 \%)\end{array}$ & $\begin{array}{l}50 \% \\
(50 \%)\end{array}$ \\
\hline $\begin{array}{l}\text { Fixed contract } \\
\text { (vs. other types) }\end{array}$ & $\begin{array}{l}33 \% \\
(67 \%)\end{array}$ & $\begin{array}{l}33 \% \\
(67 \%)\end{array}$ & $\begin{array}{l}33 \% \\
(67 \%)\end{array}$ & $\begin{array}{l}50 \% \\
(50 \%)\end{array}$ & $\begin{array}{l}20 \% \\
(80 \%)\end{array}$ & $\begin{array}{l}31 \% \\
(69 \%)\end{array}$ \\
\hline $\begin{array}{l}\text { Worked at firm for } \\
1 \text { year or more } \\
\text { (vs. less than } 1 \text { year) }\end{array}$ & $\begin{array}{l}62 \% \\
(38 \%)\end{array}$ & $\begin{array}{l}52 \% \\
(48 \%)\end{array}$ & $\begin{array}{l}60 \% \\
(40 \%)\end{array}$ & $\begin{array}{l}17 \% \\
(83 \%)\end{array}$ & $\begin{array}{l}20 \% \\
(80 \%)\end{array}$ & $\begin{array}{l}18 \% \\
(82 \%)\end{array}$ \\
\hline Total $(\mathrm{N})$ & 24 & 21 & 45 & 6 & 10 & 16 \\
\hline Mean age & 21.6 & 22.4 & 22 & 21.5 & 21.8 & 21.6 \\
\hline
\end{tabular}

Source: TIES Survey 2008

working in the same place for more than 1 year. Conversely, only a minority of the students in Strasbourg reported having worked at their job for longer than 1 year. That said, the case numbers are too low in Strasbourg to allow for a robust analysis.

In Amsterdam, most of the TIES survey participants found work in financial intermediation services and the wholesale/retail sectors, followed by hotels and restaurants. In Strasbourg, the majority worked in the wholesale and retail sector, followed by financial and healthcare services. In Amsterdam TIES data, friends and family provided access to student employment for most of the survey participants. In Strasbourg TIES data, most students used job agencies to find work, followed by their social contacts as the second most common resource. Reverting back to qualitative data, similar trends were observed with the interview respondents. Among the 25 interviewees the most popular areas of employment in Amsterdam were the retail sector-mostly in supermarkets, but also as assistants or sales advisors-and the airline industry — cleaning airplanes or working in the baggage section. There is also a notable gender division in these employment practices: airport jobs, which are physically demanding but easily accessible and well-paid, are mostly taken by males. While the majority of Amsterdam students worked in low-status jobs, some held positions that were related to their area of study — such as banking-and were expected to improve their CVs. Most jobs in Amsterdam were arranged around school hours during the week. Young people were flexible with their working schedules, and working hours ranged from 12 to 24 or more per week, with some considering full-time work during the short school vacations or over the summer. Furthermore, some participants had rather stable employment; they worked for the same employer for 2.5 years, and switched between full-time and part-time work throughout their studies. The respondents in Amsterdam mostly used their social contacts to find jobs, in addition to employment agencies (uitzendbureaus) and online advertisements. They became increasingly acquainted with certain jobs, especially those in supermarkets and airports, so they would turn to these jobs in periods of unemployment. 
Table 3.5 Sources of students' income

\begin{tabular}{l|l|l}
\hline & $\begin{array}{l}\text { Descendants of immigrants from } \\
\text { Turkey in Amsterdam }\end{array}$ & $\begin{array}{l}\text { Descendants of immigrants from } \\
\text { Turkey in Strasbourg }\end{array}$ \\
\hline $\begin{array}{l}\text { Grants and work and } \\
\text { study }\end{array}$ & $23.9 \%$ & $5.3 \%$ \\
\hline $\begin{array}{l}\text { Only work and study (no } \\
\text { scholarship) }\end{array}$ & $27.2 \%$ & $15.8 \%$ \\
\hline $\begin{array}{l}\text { Only scholarship (no } \\
\text { work and study) }\end{array}$ & $31.9 \%$ & $34.2 \%$ \\
\hline $\begin{array}{l}\text { No source of income } \\
\text { reported }\end{array}$ & $17 \%$ & $44.7 \%$ \\
\hline Total (N) & 88 & 76 \\
\hline
\end{tabular}

Source: TIES Survey 2008

In the case of the Strasbourg group, there were three main areas of employment: in the construction sector, in factories working in assembly lines, and in janitorial jobs (mostly in the Parliament). There were also smaller side jobs, such as newspaper distribution or babysitting. Another activity was doing unpaid work in the family business. In Strasbourg, many of the part-time jobs were during the summer or school vacations. However, those who were regularly employed had to work during the weekends. No respondents worked in the same place for more than 1 year, although some may have returned to the same summer job every year. Some of the Strasbourg respondents reported finding it particularly difficult to combine school with work as class attendance was obligatory and also very demanding. ${ }^{5}$ As in Amsterdam, most jobs, especially cleaning jobs, were found via social contacts. Other jobs, such as factory work and other short-term posts, were found through job agencies (office de l'intérim).

\subsubsection{Financial Motivations to Work in Amsterdam and Strasbourg}

Financial motivations are a significant impetus for student employment. The TIES survey provides information on the students' self-reported monthly income based on earnings from their part-time jobs and/or scholarships. Table 3.5 shows the distribution of income sources in both settings.

In Amsterdam, $83 \%$ of the sample reported having some sort of an income from either study grants student employment or both at the time of the survey. In addition, $34.4 \%$ reported having an income lower than $€ 550$ per month, while $44.4 \%$ of the students reported a higher income. However, in Strasbourg, only 55.3\% reported

\footnotetext{
${ }^{5}$ The level of difficulty depended on the type of study. While official hours of study do not differ greatly between the Netherlands and France, in practice higher education seems to require more class attendance in France while allowing for more autonomy in Amsterdam.
} 
Table 3.6 Activity among grant-receiving and non-grant receiving students

\begin{tabular}{l|l|l|l|l}
\hline \multirow{2}{*}{} & \multicolumn{3}{|l|}{$\begin{array}{l}\text { Descendants of immigrants from Turkey } \\
\text { in Amsterdam }\end{array}$} & $\begin{array}{l}\text { Descendants of immigrants from } \\
\text { Turkey in Strasbourg }\end{array}$ \\
\cline { 2 - 5 } & No study grant & $\begin{array}{l}\text { Received study } \\
\text { grant }\end{array}$ & No study grant & $\begin{array}{l}\text { Received study } \\
\text { grant }\end{array}$ \\
\hline $\begin{array}{l}\text { Work and } \\
\text { study }\end{array}$ & $61.5 \%$ & $42.9 \%$ & $26.1 \%$ & $13.3 \%$ \\
\hline Stage & $20.5 \%$ & $16.3 \%$ & $4.3 \%$ & $0 \%$ \\
\hline $\begin{array}{l}\text { Only } \\
\text { studying }\end{array}$ & $17.9 \%$ & $40.8 \%$ & $69.6 \%$ & $86.7 \%$ \\
\hline Total (N) & 39 & 49 & 46 & 30 \\
\hline
\end{tabular}

Source: TIES Survey 2008

having a regular income, while $44.7 \%$ had no source of income from scholarships or jobs at the time of the interview. One fourth of the students stated that they had a monthly net income of less than $€ 550$, while only $9 \%$ reported having an income of more than $€ 550$ per month.

In Amsterdam, income from grants, student employment or both was considerable, while in Strasbourg, most students seemed to be dependent on family support. This descriptive finding from the TIES survey becomes more amplified with the qualitative interviews below, where the (especially male) respondents in Strasbourg were more financially dependent on their family and felt pressure to quickly enter the labour market and drop out of education. In Amsterdam, however, similar financial pressures were eased by part-time student employment.

We also observed a relationship between receiving a grant and having a student job. In Amsterdam, 55.7\% of the sample stated that they had received some sort of study grant. Table 3.6 shows the activity distribution of those in receipt of grants compared to those who did not in both Amsterdam and Strasbourg. The table illustrates that students who did not receive a scholarship were more active in workstudy situations in both settings.

For the children of Turkish immigrants in Amsterdam there is a significant association between work-study practices and whether or not the student was receiving a study grant. Students without a grant were three times more likely to combine work and study than those who do. ${ }^{6}$ In Strasbourg, the association between workstudy combination and receipt of a grant was not significant according to a Pearson's chi-square test. Using odds-ratios, we can see that those who do not receive a grant are 2.4 times more likely to combine work and study compared to those who do.

Regarding parental financial support, parents' occupational activity was used as a proxy as the TIES Survey did not provide information on the parental household income.

Table 3.7 illustrates patterns of employment among the parents of the respondents who were still studying at the time of the survey. While there is no information on their parents' income level, $31.8 \%$ of the respondents reported that their fathers

${ }^{6}$ Pearson's chi-square was significant: $x 2(1)=5.17 \%, p<0.05$. 
Table 3.7 Students' Parents' occupation

\begin{tabular}{l|l|l|l|l}
\hline & \multicolumn{2}{|l|}{$\begin{array}{l}\text { Descendants of immigrants from } \\
\text { Turkey in Amsterdam }\end{array}$} & \multicolumn{2}{l}{$\begin{array}{l}\text { Descendants of immigrants from } \\
\text { Turkey in Strasbourg }\end{array}$} \\
\cline { 2 - 5 } & Father & Mother & Father & Mother \\
\hline Working & $43.2 \%$ & $30.6 \%$ & $75 \%$ & $44.7 \%$ \\
\hline Seeking work & $2.3 \%$ & $3 \%$ & $3.9 \%$ & $9.2 \%$ \\
\hline $\begin{array}{l}\text { Sick or otherwise } \\
\text { inactive }\end{array}$ & $31.8 \%$ & $27.3 \%$ & $9.2 \%$ & $3.9 \%$ \\
\hline Retired & $6.8 \%$ & $2.3 \%$ & $6.6 \%$ & $1.3 \%$ \\
\hline Caring for children & $0 \%$ & $29.5 \%$ & $0 \%$ & $39.5 \%$ \\
\hline Missing/DK & $15.9 \%$ & $6.8 \%$ & $5.2 \%$ & $1.3 \%$ \\
\hline
\end{tabular}

Source: TIES Survey 2008

were inactive or on sick leave compared to $9.2 \%$ in Strasbourg. Hence in Amsterdam only $55 \%$ of the sample had at least one employed parent, whereas $45 \%$ reported both parents as being inactive or unemployed. In Strasbourg, however, 85\% of students had at least one parent active in the labour market. The differences in parental activities are in line with previous literature. In Amsterdam there has been a sharp decrease in the employment of Turkish first-generation migrants since the 1990s due to the closure of the garment industry and the remaining manufacturing business (Rath 2002; CBS 2004). In France, even though members of the Turkish first generation were more likely to be unemployed than native-born French, their activity rates were higher than those in Amsterdam as 2/3 of the Turkish migrants reported being active (Perrin-Haynes 2008). We found no significant association between parental activity and the students' work-study combination. However, concentrating on the odds-ratios reveals that, in Strasbourg, native-born descendants of Turkish immigrants with two inactive parents are 2.6 times more likely to combine work and study compared to those who had at least one active parent. In Amsterdam, those with two inactive parents are only 1.2 times more likely to combine work and study than those with at least one employed parent. As a result, students in Strasbourg whose parents were not active in the labour market are more likely to combine work with study than students in Amsterdam.

All in all, despite the limitations of the TIES survey data, the descriptive analysis reveals striking differences between the settings. Respondents in Amsterdam combined work and study more often and reported wider access to scholarships compared to the respondents in Strasbourg. We can argue that not having other means to support their studies, respondents in Strasbourg were more dependent on parental support. This was also reflected in the relationship between parental activity and the likelihood of working and studying: those with inactive parents were more likely to work compared to their counterparts in Amsterdam. The qualitative interviews below shed more light on this distinction between the two settings.

For the respondents in the qualitative interviews, financial reasons also formed the major impetus for student employment among respondents. In Amsterdam, all 
respondents resided in the same household as their parents during their studies. ${ }^{7}$ Most students received a student finance grant called studie financiering, ranging from $€ 100$ to $€ 500$ per month depending on their parents' income and place of residence. However, the students stressed that these grants did not cover all of their expenses, but just supplemented their income. Soner, a final-year student in postsecondary vocational education (MBO) studying commerce (Handel in Dutch), was working in a phone store at the time of the interview. He had always had stable part-time employment since the age of 16 . He had worked for at least 2 years in each of his jobs. His main motivation for changing employment was higher pay. He stated that scholarship funds only covered some of his primary needs, and that he had to work to supplement them:

INTERVIEWER: What do your parents do?

SONER: My dad works. My mum sometimes [works]; once or twice a week if necessary. Now I get studie (study aid), but there's nothing left after tuition, health insurance and the phone bill. So I have to work. I mean, you have to work; there is nothing left. It is expensive here you know.

Even among students with low-income parents, the family's financial situation was not mentioned as providing "an obligation to work." The objective conditions-in this case the parents' financial standing and the scarceness of study grants-led more students to see part-time work as the most "reasonable" activity (Bourdieu 1977, p. 77). Irrespective of their parents' financial position, the earnings from these part-time jobs did not contribute to household income. This income was for the respondents to pay for their personal expenses such as school fees or consumer goods. Gül, a final-year HBO student at a tertiary vocational school, had had an intensive student employment career since the age of 16 . She mentioned that she had a considerable income, and that she mainly spent it on clothes. While she didn't share her income with her parents, she also did not ask them for money.

GÜL: First I worked in a store. When I was 16 I think I worked for two years there or something, but, while I was working there, I found my other job. I have always done two jobs at a time. I can't get enough money, you know, that's what my mother says. My closet is always full. (giggles)

INTERVIEWER: How many hours per week would you work?

GÜL: I became greedy with money; I worked a lot! First in Blocker and also in the phone company. I was working every single day. I had quite a good salary at the end of the month.

Increased consumption was both an important outcome and a major motivator of student employment among my respondents. Previous research on youth sociology has shown how participation in the consumer economy has become an integral part of young people's lives, and is even considered as one way of becoming an adult (du Bois-Reymond 2009b). As Best argues (Best 2009), young people purchase and use goods in the consumer market to construct certain identities and to set themselves apart from their parents. Şakir, who dropped out of post-secondary vocational

\footnotetext{
${ }^{7}$ Those who lived with their parents only considered leaving home after getting married. Some students even continued to live with their parents or in-laws after marriage due to difficulties finding social housing or affordable childcare.
} 
education (MBO), works as a security guard and lives with his parents. He began working at the airport when he was 16 , and had been quite stably employed there for 4 years before becoming a security guard. Asked about his current income and whether he thought it was sufficient, he responded as follows:

ŞAKIR: Something happened here, how should I say? My parents are different, my parents do not get dressed up, they do not go out like I do. They are second generation and I am third generation, and there is a huge difference between these two. Why? Because they [my parents] came here, they don't speak Dutch, they purchase only the cheapest things, they don't do certain things, they have to take care of us. They came under these circumstances with the idea of returning [to Turkey] someday. But we are not like that. I am born here. I grew up here. Hence I have to spend the rest of my life here. I take this into consideration when I make each of my steps; I think that I will live here for the rest of my life. I speak Dutch, English, and Turkish; I have learned things over time. There is a big difference between my parents and me. [There is] also [a difference] between my grandparents and my parents.

Şakir articulates his "lifestyle choices", in terms of how he dresses and spends his leisure time, as distinguishing him from his parents (Best 2009, p. 256). He uses this distinction to emphasize the difference in social standing that had developed ("something happened here") between himself-a member of the "third generation" _ - and his parents, who were second generation "immigrants", trying to sustain their families on a minimum income and dreaming of returning to Turkey. Born and raised in the Netherlands, Şakir set himself apart with regard to his qualifications, future prospects, and also his tastes. Student employment has thus provided native-born descendants of Turkish immigrants with purchasing power, and this consumerism has become an integral part of their lives.

All of these respondents lived in the same household as their parents and depended on them for shelter, food and services such as laundry and cleaning. However, by not taking money from their parents and paying for their own expenses, they were articulating a sense of "independence" and building "responsibility." This feeling of independence becomes vital during the transition process, when young people are deciding whether to enter the labour market or pursue their studies into higher education. Especially for vocational students, having financial independence from their parents relieves economic concerns that would otherwise create pressure to enter the labour market. Ufuk was a vocational student with low-income parents. He had been working at the airport since the age of 16 . He explained his future plans as follows:

INTERVIEWER: What is your next step?

UFUK: I am planning to attend HBO [tertiary vocational education]. Some say it's hard, but I want to try...

INTERVIEWER: Do you have to pay for that school?

\footnotetext{
${ }^{8}$ Şakir provides an alternative conceptualization of generations. He classifies his father, who arrived in the Netherlands after his grandfather, as second generation, and himself as third generation, born and raised here. According to statistical definitions, his father is classified as 1.5 generation while he is second generation. This shows how the definition of generations varies among respondents.
} 
UFUK: Well some, not much. I've looked into some websites and been to a few open days where they talk about the schools, you know. But money is not an issue, you know; if you work part time, you make money.

Although Ufuk's vocational diploma qualified him to enter the labour market, he didn't seem to be in a hurry and wanted to try tertiary education first. Similarly, Sencer decided to access higher tertiary education after his vocational training. He did not ask his family's permission as he was paying his own school expenses.

SENCER: I didn't really ask them you know. I am the one who pays for the school, for the books. I haven't asked my parents for money since I was sixteen you know. Of course, they were OK with what I did in the end.

In Strasbourg, by contrast, students under financial obligations could feel pressure from their parents to start working. As in Amsterdam, all of the respondents in Strasbourg lived with their parents during their studies. Only those in tertiary vocational education (BTS) or university were eligible for grants those in high school (bac) or vocational training (CAP/BEP) were not. As a result, only a minority of the Strasbourg respondents were receiving a grant. These grants ranged from $€ 150$ to $€ 430$ per month, depending on family income, the number of siblings attending school, and the distance between their family's residence and the institution.

The Strasbourg students reported that their grants did not to cover their expenses. Nevertheless, they expressed gratitude for this income rather than dissatisfaction, saying it was "better than nothing." Since both access to and the amount of these grants were very limited, the motivation to combine work and study was contingent on the financial support provided by their parents. Whereas financial support from one's family did not strongly influence the decision to work in Amsterdam, in Strasbourg it determined whether or not someone worked on a regular basis. As combining study with a regular job was quite demanding, only those who felt a financial obligation to work regularly chose to.

Behzat had high grades for his vocational diploma (BEP) and was advised to continue his studies. He went to high school and obtained his professional baccalauréat (bac pro.) before embarking on tertiary vocational training (BTS). His parents were not able to support him financially and he had to work to pay for his personal expenses:

Behzat: I used to work during the holidays-in factories for example - and this was where the problem began. When the semester started, these jobs called me back to work. At first, I went to work at weekends and to school on weekdays. Sometimes I would even work during two days of school. Then I would feel very tired. I had to work because my father and my mother are both retired. My brother and my sister got married and moved to their own homes. So I was the only child living with my parents, and I didn't want to be a burden on them. I wanted to make my own money. I was 18 back then. I didn't want to have to ask my parents for money.

INTERVIEWER: How come?

Behzat: Because all my friends had already started working. But I hadn't. They paid for their own driving licenses. They had cars, but I didn't. I had also learned a trade and I told myself I could also make money and pay for my driver's license. I regret it. I wish I had finished my BTS (tertiary vocational diploma). It is getting very difficult to find a job without a BTS these days. 
Behzat had 5 days of intensive classes, which did not make it easy for him to combine work and study. He remembers that his father once asked him; "How long are you planning on studying?" Even though this was not an overt suggestion he quit school, all the conditions surrounding him suggested that entering the labour market was the right thing to do: his parents expected him to work, he already had a vocational degree, and all his friends were working. Today he regrets his decision: although he has a good job, he fears that should he become unemployed he will not find decent work again without a BTS degree. Behzat's case also points to the significance of gender roles and the male working-class culture that surrounds many of the male respondents. Although these youths are in favour of higher educationcontradicting theories of resistance among working-class males (Willis 1977) - it is not an easy goal to pursue given their circumstances. As illustrated in the previous chapter on education, most native-born descendants of immigrants from Turkey are advised to pursue vocational degrees (BEP/CAP), which do not provide direct access to higher education, and thus have to pursue a longer track to university. As they get older, these males need more money for their private expenses. Hence, for some, student employment becomes a necessity, especially if they want to stay in education. During lower secondary school (collège), Cengiz was a successful student but he was advised to take the vocational track, a decision he did not oppose. His parents were also supportive of his wish to take the vocational track since they wanted him to learn a trade. However, once in vocational education, he was advised to continue into higher education due to his good grades. His family already had a supermarket business, where he had been working after school until late at night. This situation became problematic when he began higher education;

CENGIZ: In my first year of professional lyceum, my parents already had the supermarket business. I was going there to work every day after school to help them. But it was too much. I was fed up. I said either I should drop out of school or quit the job, but I couldn't do both. Doing both, I was also unable to study properly. You could tell from my grades. At the vocational school (BEP), I had no difficulty; I never had to study. I was again working for my family, but it was easy. The vocational programme was so easy; I think it was even easier than secondary school (collège). It was the year I started the vocational school that my parents got the supermarket. I went there [to work] every night. We were all motivated by having our own business. We were comparing ourselves to others who had a supermarket and how much they were making. So I was working. It was also our pocket money. My dad said, "You can get whatever you want." But when things changed when I started high school.

INTERVIEWER: How did they change?

CENGIZ: The courses became more difficult because I was working so much. I finished the first year. I passed my classes but my grades were not that good. In vocational school my average was $15 / 20$ but in high school it went down to 10/20. My teachers said I should come the next year but I talked to my father and told him that I did not want to continue with school.

INTERVIEWER: How did he react?

CENGIZ: Look, I had my trade; I had a profession. He only said, "Do as you like, but don't come and say it was because of me."

Cengiz was accustomed to working during vocational school, but everything changed once he started lyceum. The fact that he already had a "trade" created a 
psychological safety net that allowed him to quit education. Yet, having dropped out, Cengiz neither worked in the family business nor in the area of his profession (plumbing); instead, he did all sorts of menial jobs, from delivery to factory assembly. Unlike Behzat, Cengiz did not express any regrets about his decision to drop out. He was only unhappy about his choice of trade, and he wished he had studied car mechanics instead of plumbing.

Conversely, while Deniz had also had to work regularly because of her family's financial difficulties, her job actually motivated her to obtain a degree:

DENIZ: I worked in factories and did cleaning jobs-maybe six or seven jobs like that over the course of my studies in high school and higher education. It was hard. Don't get me wrong, I did all those jobs willingly; in the end, I made money and I'm grateful. I never looked down on them; they taught me a lot. These jobs made me more dedicated to my studies; even today, they remind me how lucky I am to have my current job.

Unlike Behzat and Cengiz, Deniz had parents who were very supportive of her educational track despite their lack of affluence. Her father painted building exteriors as a profession and even worked extra hours to pay for private lessons to help her to catch up with her classes. Deniz felt responsible towards her father to make an income so as not to be a burden on her family.

In fact, as in Amsterdam, the majority of the Strasbourg respondents felt the need to work part time for their personal expenses, yet none used their earnings to contribute to their family's income. These earnings were their own; to pay for their consumer needs or living expenses and gain a sense of responsibility.

The second group of students were those who had no obligation to work due to their family conditions, but still wanted to earn towards their personal or living expenses. They worked during holidays or summer breaks to earn pocket money for their visits to Turkey or for purchasing consumer goods. Veli, a university student, worked all summer to earn spending money for the rest of the year:

VELI: I always worked in the summers. I would work with my father and my uncle on the construction site. I also worked in a restaurant. I would earn my pocket money because I didn't always study here. I studied outside [of Strasbourg] for three years; two years in Lille and one year in Nancy. I tried to earn at least the cost of my gas bill by working in the summer.

INTERVIEWER: How long would you work for?

VELI: About a month, I would say. I had holidays for one month.

INTERVIEWER: What do you think about your experience?

VELI: Not much. I just earned some money; nothing more than that.

Financial motivations are the main trigger for student employment among the majority of native-born descendants of immigrants from Turkey, both in Amsterdam and Strasbourg. Even if their family is low on funds and student grants don't cover their expenses, students can still engage in a consumer lifestyle and establish a sense of responsibility and independence while living at home thanks to their part-time, temporary jobs. The striking difference between the two settings was that while it was rather easy for students in Amsterdam to combine regular employment with studying, in Strasbourg it was difficult for students to combine both activities on a 
regular basis. In Strasbourg, regular work and study combinations posed a risk to students' educational trajectories and those who worked regularly during their studies struggled to stay in education. Especially male respondents felt more pressured to work and ended up dropping out of school due to their working activities. On the contrary, in Amsterdam, student employment practices eased the immediate financial pressure to start working and this enabled them to experience rather extended and flexible transition processes, in which they either alternated work and study or did both. We can even say that for some students, working part time enabled them to prolong their studies into higher education, though whether they succeeded in obtaining a diploma was uncertain at the time of the interview.

\subsubsection{The Role of Family Support and Students' Educational Capital in Choice of Part-Time Jobs in Amsterdam and Strasbourg}

Even though financial motivations were the main trigger for the majority of the respondents to combine work and study, some experienced and benefitted from student employment in a different manner. Previous research demonstrates that higher education students are more likely to combine work and study, as are older students (Lucassen 2003). The TIES survey shows similar patterns. In the TIES sample, the majority of the students who combined work and study were in higher education. Nevertheless, there was no significant association between being in higher education and combining work and study than being in vocational or higher secondary school and doing so. In this section I will study a trend which was made visible by the qualitative data as the TIES survey was cross-sectional and it was not possible to discern the influence of student employment on future transitions. When asking retrospective questions in the qualitative interviews, it became evident that some respondents also turned their student jobs into future social capital and work-related knowledge for finding jobs. This was striking among those with higher educational achievements and whose parents provided financial support since they were likely to choose jobs related to their studies and tended to see their work experience as an important credential for the labour market. Clearly, a socioeconomic differentiation has developed among the immigrant parents from Turkey since their arrival in the 1970s, as some have accumulated more financial, social and educational capital during their stay in the host country. Student employment practices within and across settings make it evident that some have accrued certain advantages. Students who could rely on their parents' financial capital said that their fathers not only paid for their school costs, but also for their consumer needs. This allowed them to focus on finding student jobs that would ultimately provide important credentials for entering the labour market, such as developing social capital or work-related information capital. Melek, a third year vocational tertiary education (HBO) student studying 
Business \& Economics reported that her parents covered all of her expenses. When asked about her student employment experiences, she said she had never worked in any menial job, such as a supermarket, but had instead applied for jobs related to her field of study:

INTERVIEWER: What are the most important elements when you are looking for a job after graduation?

MELEK: Qualifications, self-confidence, but also work experience. I think work experience is the most important. [Employers] still expect you to have done a part-time job in addition your studies. They expect that. If you have that experience, you receive priority [in the hiring process]. In order to minimize the risks of unemployment, I am trying to fill in my $\mathrm{CV}$ with experience at good companies.

INTERVIEWER: How?

MELEK: Via internships and student employment. For example, in my second year, even though it was very difficult, I still worked. Because I thought that, in this way, I could find an internship a lot more easily the next year.

At the beginning of her second year, Melek started looking for a job related to her studies through an employment agency website. She managed to arrange a part-time job (16 h per week) in a prestigious international audit company, $\mathrm{PwC}$ - a name she was unfamiliar with before her job search. She claims that it was only through people's reactions to the name that she understood how good a company it was and believes that this part-time job improved her chances of finding a good internship in her third year. For Melek, as a self-described "allochtone girl wearing a headscarf", these experiences were vital to improving her future chances in the labour market. ${ }^{9}$ First of all, Melek made business contacts by working in this company, which helped her to accrue job-related social capital. Furthermore, seeing other headscarfwearing women working in such a prestigious company helped build her selfconfidence about working in a similar environment in the near future. Having the name of such a firm on her CV clearly functions as symbolic capital for future employers.

Similarly, Bulut's parents covered her expenses and mobilized every family resource to assist her studies. She had just finished her MA degree after completing a HBO degree in Business \& Economics. Bulut was concentrating on internships and part-time jobs in the area of her studies. She highlighted what we may call symbolic capital with regard to the symbolic importance of "where one works" rather than "what one does" and how these positions were not only significant for her CV but also for providing crucial social capital for her future transition. These examples show how in the presence of parental support, combining work with studying could help young people to build forms of capital.

However, not all respondents with more financial resources worked in careerrelevant student jobs, while some from less affluent backgrounds did. Some MBO students conducted dual training, combining 4 days of work with 1 day of study.

\footnotetext{
9 "Allochtone" is a pejorative term used in the Netherlands to refer to ethnic minorities. However, it is important to underline that this terminology is being used by the respondents themselves to express their fears about how discrimination and stereotyping in the labour market might make it hard for them to find a position.
} 
Others transformed their internships into part-time employment or vice versa. For example, Nevin was a MBO student who found her scholarship grant too meagre and wanted to combine her studies with part-time employment. She was not happy with her job in a wholesale store because it was too strenuous for her. She managed to gain a position 4 days a week at the company where she had done her internship, going to school just 1 day a week. Nevin claimed to have enjoyed work more than school, and didn't mind finishing MBO in 3 years rather than two. In Amsterdam, most respondents were very conscious of the need to build and invest in their CVs. The major difference between higher education students working in their area of study (i.e. Melek and Bulut) and vocational students (i.e. Nevin and Hakan) was that the first group was more aware of the "symbolic value" of company names or social capital that would make it easier to get a good job after graduation. Higher education students were also more concerned about developing symbolic social capital for their future careers as they could not access any such contacts via their parents. When this knowledge is supplemented by family financial capital as well as emotional capital for their future mobility, young people are more easily able to access the kind of part-time work that is directly aligned with their studies, usually resulting in a more desirable job upon graduation.

In Strasbourg, none of the respondents had student jobs in their area of study. However, this might have been a sampling issue rather than a structural constraint as previous research has underlined that students with parents in managerial positions generally had study-related jobs and experienced smoother transitions to the labour market (Béduwé and Giret 2004).

Nevertheless, some respondents were inclined to undertake institutional workstudy combinations in the form of dual training to be able to work in their area of study. This is different from the examples in Amsterdam in that those in Amsterdam arranged part-time jobs next to their studies while those in Strasbourg looked for a job as part of their studies. This sort of combination was mostly utilized for tertiary vocational training (BTS), especially if students were attending a private institution. "Dual training" in BTS (BTS en alternance) involves 4 days of work and 1 day of study per week. It requires young people to find an employer who is willing to hire them and pay for their schooling in return for low-cost employment and tax reductions. However, it is difficult to find companies willing to commit to such an arrangement. Engin looked for a company where he could follow dual training for 2 years after receiving his high school diploma (bac tech.) because he wanted to combine his studies with a job in a related field. After sending more than 100 applications he eventually gave up on the idea and entered the labour market with only a high school diploma. By contrast, Selin managed to find a Turkish company willing to hire her thanks to her father's and uncle's extended networks. However, when this arrangement didn't work out and she had to change her employer, having had work experience made it easier for her to find another place where she could combine work and study for 2 years after high school. She later made a smooth transition to the labour market by staying with this second (French) company. Selin didn't have a student job or summer job at any point in her education as she had the full financial support of her family. Similarly, Gönül had to drop out of university due to a 
personal problem, but mobilized her family networks to find internships and an employer prepared to undertake a dual programme. Despite this help, Gönül's transition also didn't go smoothly. Her father arranged an internship in Germany with a Turkish employer, but this did not work out. After 1 year she was able to find another employer, this time of French origin, who was prepared to finance her dual training and she remained in this job after finishing her studies. As this example demonstrates, both their parents' financial and social capital and an individual's own educational capital are instrumental in facilitating employment or at least in gaining entry to the labour market. In both examples the parents provided some sort of entry despite their limited resources.

In both settings, those in higher education who had full financial support from their family were able to organize their student employment to their own career advantage. In Amsterdam, these students chose jobs which would have symbolic value in their resumes and would count as relevant work experience. Students in higher education were particularly aware of the importance of developing studyrelated work experience. This enabled them to develop social capital, symbolic capital and work-related information capital that they were unable to access via their families (as none of their parents were highly educated but rather operated successful businesses that allowed them to support their families financially). In Strasbourg, the respondents who were studying in a dual programme for vocational tertiary education (BTS en alternance), had to find an employer themselves before they could enrol in the programme. Hence parental connections and resources mattered. This is important as previous research in France has shown that those who worked in jobs in their area of study were more likely to make a successful transition to the labour market. This was also found to be the case among this study's respondents: those who were able to conduct a study-related dual study ended up staying in the same company once they graduated and therefore experienced very smooth transitions. Similar to Amsterdam, students who had graduated from tertiary education and were looking for a work in the highly-skilled professional labour market were unable to rely on parental resources.

\subsection{Conclusion: Implications of Work and Study Combinations}

Kasinitz and his colleagues (2008) have warned of the lack of attention currently paid to student employment among second-generation youth. Their data provided hints that student jobs could have a significant impact on the pathways of descendants of migrants as their migrant parents are unable to transmit much in the way of resources for either their education or their entry into the labour market. A meticulous study of student employment experiences among native-born descendants of migrants from Turkey shows the significance of this activity for their youth 
transitions. Furthermore the extent and nature of this influence differed across both settings. Both the quantitative and qualitative findings show that the young people in Amsterdam were more active in the labour market during their studies compared to their counterparts in Strasbourg, confirming existing trends in the Netherlands and France (Wolbers 2008). Such variation could not be attributed to labour market differences. In Amsterdam, state policies decreased scholarship access and individualized the cost of education for students via loans (Vossensteyn 1999, 2002). This was met with an increased labour market demand for low-skilled or unskilled labour and an increase in the value attributed to professional experience by the education system. This series of developments created a situation in which students, irrespective of parental financial capital, saw student employment as a "natural" activity. As well as facilitating consumerism, student employment provided a way for respondents to feel responsibility and independence while continuing to live with their parents (Best 2009). This financial independence played a pivotal role during the transition process: native-born descendants of immigrants from Turkey in Amsterdam felt less pressured by financial obligations to enter the world of work, and were thus able to extend their studies, enter tertiary education and experience rather more flexible transition processes. Financial pressures were most visible among male respondents: in both settings gendered motivations were observed among male respondents who felt more pushed to gain an income at an early age. Yet male respondents in Amsterdam managed this pressure by combining their studies with work and gaining a certain independence in their transition decisions.

In Strasbourg, state policies promoted student employment in order to pass on the costs of higher education (due to meagre scholarships opportunities) and also encouraged the professionalization of education by citing job experience as an important credential (OVE 2006). However, these policies were not yet wholly supported by the labour market and the school environments. The labour market was unable to provide flexible employment for students, offering rather precarious working conditions instead. Schools also enforced strict class attendance rules, making it hard for students to combine work and education without jeopardizing their studies. This created tension for students who wanted to pursue their education but did not have the means to do so, even more so if they did not receive sufficient grants. Furthermore, the lack of part-time employment opportunities often meant that leaving education and accessing the labour market were the only options for students with financial obligations.

The intention here is not to praise student employment opportunities. In fact, student employment proved to be both physically and mentally very demanding for many respondents and was often detrimental to their studies. In Strasbourg participating in student employment led to some respondents dropping out of education. Yet it needs to be underlined that the majority of the youngsters in this study, and also in general within the Turkish communities of Amsterdam and Strasbourg, grew up in poverty. These families, which often had many children, were seriously limited 
in their ability to offer financial support. Hence, student employment eased transition for respondents in Amsterdam from low-income families, enabling them to participate in a consumer lifestyle and gain a sense of financial independence without dropping out of education altogether. Our quantitative analysis showed that the 83\% of the sample reported having some sort of an income from part-time employment, scholarships or both. However, in Strasbourg, family resources remained the main source of student income, as only 55\% of students reported having some sort of an income, mainly from grants. In both settings, those without a grant were more likely to participate in student employment, which put their educational participation at risk and created conditions that led many of them to drop out.

In addition to gaining financial independence and pursuing a consumer lifestyle, some respondents even managed to make considerable contributions to their future labour market careers. Student employment exposed young people to a work environment where they learnt general skills, such as managing working hours, dealing with colleagues and various other realities of employment that they had been unaware of as students. They developed social capital that proved instrumental to their labour market transitions. Nevertheless the beneficial nature of student employment varied, depending on the family's financial and social capital and the student's own education capital. Accessing a study-related job or doing dual training provided significant advantages for transitions from education to work. Working in such jobs and placements enabled students to develop both cultural and social capital in their area of study and made a positive contribution to their transition. Confirming the hypothesis of Kasinitz and his colleagues (2008), such capital development in one's social trajectory is crucial for young people who are not from privileged backgrounds.

\section{References}

Béduwé, C., \& Giret, J. F. (2004). Le travail en cours d'études a-t-il une valeur professionnelle? Économie et Statistique, 378-379, 55-83.

Bérail, M. L. (2007). Le Travail des Étudiants. Journal Officiel-Republique Francaise Avis Et Rapports Du Conseil Economique Et Social, 25.

Best, A. L. (2009). Young people and consumption. In A. Furlong (Ed.), Handbook of youth and young adulthood: New perspectives and agendas (pp. 255-262). London: Routledge.

Bourdieu, P. (1977). Outline of a theory of practice. Cambridge/New York: Cambridge University Press.

Brooks, R. (2006). Learning and work in the lives of young adults. International Journal of Lifelong Education, 25, 271-289.

CBS. (2004). Allochtonen in Nederland En Leefsituatie. Den Haag: CBS[Host].

CBS. (2012). Turkse Ingezetenen in Nederland 2011. Den Haag: Centraal Bureau Voor Statistics.

Cereq. (2001). Premiers Pas Dans La Vie Active De La Génération 1998. Paris: Cereq.

Cereq. (2007). Premiers Pas Dans La Vie Active De La Génération 2004. Paris: Cereq. 
Cereq. (2014). Quand l'école est finie.Premiers Pas Dans La Vie Active De La Génération 2013. Paris: Cereq.

Delsen, L., \& Poutsma, E. (2005). Labour market institutions and economic performance in the Netherlands. International Economic Journal, 19(2), 169-196.

$\mathrm{Du}$ Bois-Reymond, M. (2009a). Integrated transition policies for European young adults: Contradictions and solutions. In I. Schoon \& R. K. Silbereisen (Eds.), Transitions from school to work: Globalization, individualization, and patterns of diversity (pp. 331-352). New York: Cambridge University Press.

Du Bois-Reymond, M. (2009b). Models of navigation and life management. In A. Furlong (Ed.), Handbook of youth and young adulthood new perspectives and agendas (pp. 47-54). Oxon: Routledge.

Eurydice. (2007). The education system in the Netherlands 2007. The Hague: Ministry of Education, Culture and Science.

Eurydice. (2008). Organisation of the education system in France. Paris: Ministry of Education.

Jamet, S. (2006). Improving labour market performance in France. Paris: OECD.

Kasinitz, P., Mollenkopf, J. H., Waters, M. C., \& Holdaway, J. (2008). Inheriting the city. The children of immigrants come of age. New York: Russell Sage Foundation.

Lucassen, S. C. H. H. L. (2003). Bijbanen van onderwijsvolgende jeugd. CBS, Sociaal-economische Maandstatistiek, 2, 16-18.

McNeal, R. B., Jr. (1997). Are students being pulled out of high school? The effect of adolescent employment on dropping out. Sociology of Education, 70(1), 206-220.

Mueller, W., \& Gangl, M. (Eds.). (2003). Transitions from education to work in Europe: The integration of youth into EU labour markets. Oxford: England University Press.

OVE. (2006). Présentation Des Principaux Résultats De L'enquête Conditions De Vie Des Étudiants 2006 [Presentation of the principal results of the survey on students life conditions]. Paris: Observatoire De La Vie Étudiante.

Perrin-Haynes, J. (2008). Principal: L'activité Des Immigrés En 2007.

Pigeaud, R., Clarens, V. D., Paty, M., Balmer, L., \& Roussel, R. (2009). VET in Europe- Country report France. Cedefob.

Pinto, V. (2010). L'emploi Étudiant Et Les Inégalités Sociales Dans L'enseignement Supérieur. Actes De La Recherche En Sciences Sociales, 183, 58-71.

Powell, J. J., Coutrot, L., Graf, L., Bernhard, N., Kieffer, A., \& Solga, H. (2009). Comparing the relationship between vocational and higher education in Germany and France (No. SP I 2009506). WZB Discussion Paper.

Rath, J. (2002). A quintessential immigrant niche? The non-case of immigrants in the Dutch construction industry. Entrepreneurship \& Regional Development, 14(4), 355-372.

Riele, S. T., \& Siermann, C. (2007). Bijna Een Miljoen Mensen met Een Kleine Baan. Sociaaleconomische Trends. 2nd-quarter, 36-39.

Ruhm, C. J. (1997). Is high school employment consumption or investment? Journal of Labor Economics, 15(4), 735-776.

Schoon, I., \& Silbereisen, R. K. (Eds.). (2009). Transitions from school to work: Globalization, individualization, and patterns of diversity. New York: Cambridge University Press.

Van der Meer, P., \& Wielers, R. (2001). The increased labour market participation of Dutch students. Work, Employment and Society, 15(1), 055-071.

Visser, K. (2010). VET in Europe- Country report the Netherlands. CEDEFOB.

Vossensteyn, J. J. (1999). The financial situation of students in the Netherlands. European Journal of Education, 34(1), 59-68.

Vossensteyn, H. (2002). Shared interests, shared costs: Student contributions in Dutch higher education. Journal of Higher Education Policy and Management, 24(2), 145-154. 
Wauquiez, L. (2006). Les aides aux étudiants les conditions de vie étudiante: Comment relancer l'ascenseur social? Paris: La Documentation Française.

Willis, P. E. (1977). Learning to labor: How working class kids get working class jobs. Farnborough: Saxon House.

Wolbers, M. H. (2003). Combinaties van werken en leren onder jongeren in Europa. Tijdschrift voor Arbeidsvraagstukken, 19(1), 20-33.

Wolbers, M. H. J. (2008). Scholieren met een bijbaantje: de gevolgen voor hun schoolprestaties. Mens \& Maatschappij, 83(3), 239-257.

Wyn, J., \& Dwyer, P. (1999). New directions in research on youth in transition. Journal of Youth Studies, 2(1), 5-21.

Zdrojewski, S., Grelet, Y., \& Vallet, L.-A. (2008). Increasing employment instability in France? Young people's labor market entry and early career since the 1990s. In H. Blossfeld (Ed.), Young workers, globalization and the labor market: Comparing early working life in eleven countries (pp. 103-127). Cheltenham: Edward Elgar Publishing.

Open Access This chapter is licensed under the terms of the Creative Commons Attribution 4.0 International License (http://creativecommons.org/licenses/by/4.0/), which permits use, sharing, adaptation, distribution and reproduction in any medium or format, as long as you give appropriate credit to the original author(s) and the source, provide a link to the Creative Commons licence and indicate if changes were made.

The images or other third party material in this chapter are included in the chapter's Creative Commons licence, unless indicated otherwise in a credit line to the material. If material is not included in the chapter's Creative Commons licence and your intended use is not permitted by statutory regulation or exceeds the permitted use, you will need to obtain permission directly from the copyright holder. 